\title{
Epidemiology of Hepatitis C Virus in Bangladeshi General Population
}

\author{
Mamun-Al-Mahtab ${ }^{1}$, Salimur Rahman², Fazal Karim³, Graham Foster ${ }^{4}$, Susannah Solaiman ${ }^{5}$ \\ ${ }^{1}$ Assistant Professor, ${ }^{2}$ Professor, Department of Hepatology, Bangabandhu Sheikh Mujib Medical University, Dhaka, Bangladesh, ${ }^{3}$ Consultant \\ Medicine, Dhaka Mohanagar Hospital, ${ }^{4}$ Professor, ${ }^{5}$ Research Fellow, Digestive Diseases Research Centre, Bart’s and the London Queen Mary's \\ School of Medicine and Dentistry, London, UK.
}

\begin{abstract}
Background: Hepatitis C virus is encountered sporadically in Bangladesh. It results in a wide range liver diseases, with asymptomatic acute hepatitis rarely at one end to HCC at the other end of the spectrum. Methods: 1018 individuals of different age groups and sex with varied religious, educational and social backgrounds were tested for anti-HCV by ELISA. Before testing, blood samples were preserved at $-20^{\circ} \mathrm{C}$. The study was conducted in a semi-urban location on the outskirts of Dhaka. Results: $0.88 \%$ tested positive for anti HCV. None of them tested positive for HBsAg. There was a male predominance and those who tested positive were mostly between 17 and 50 years of age. Major risk factors for exposure to HBV appeared to be injudicious use of injectable medications, treatment by unqualified, traditional practitioners, mass-vaccination against cholera and smallpox, barbers and body piercing. Conclusion: HCV remains an important cause of morbidity and mortality in Bangladesh.
\end{abstract}

Key words: HCV, prevalence, general population, Bangladesh.

[BSMMU J 2009; 2(1): 14-17]

\section{Introduction:}

Although hepatitis C virus (HCV) related chronic liver disease is common in our clinical practice, unfortunately there is lack of representative population study in Bangladesh regarding the prevalence of the virus. This present study is among the handful where the seroprevalence of HCV in our population has been studied.

Except for the work by a Japanese group, that reported $5 \%$ prevalence of HCV in Bangladesh ${ }^{1}$, others reported extremely low prevalence of HCV in Bangladesh ${ }^{2}$. This gives the impression that the impact of $\mathrm{HCV}$ in Bangladesh is negligible. On the other hand a British study has shown that $45.3 \%$ and $56 \%$ of British-Bangladeshi patients with chronic liver diseases and hepatocellular carcinoma respectively have been infected with $\mathrm{HCV}^{3}$. There are also published data from Bangladesh identifying HCV to be the etiological agent in $24.1 \%$ of patients with chronic liver diseases in Bangladesh ${ }^{4}$. All these diversifying reportings make it essential to revisit the prevalence of HCV in this country, especially among the apparently healthy individuals.

Correspondence to : Dr. Mamun-Al-Mahtab, Assistant Professor, Department of Hepatology, Bangabandhu Sheikh Mujib Medical University, Shahbag, Dhaka-1000, Bangladesh, Email: shwapnil@agni.com

\section{Materials and methods}

The study was conducted in the Savar area on the outskirts of Dhaka in May 2007. The area has a large industrial base. The leading export processing zone of the country is also situated here. People from all over the country stay and work in different industrial and other installations in this area. Moreover, due to its proximity and excellent communication with Dhaka city, many people from different parts of the country reside here and commute to Dhaka daily for work and business. It was therefore assumed that the study population was representative of the Bangladeshi population.

Before the samples were collected, several meetings were held with local political, social, religious and business leaders in order to ensure community participation and full cooperation. We arranged mass propaganda to encourage people to participate in the study. During Jumma prayers, Imams (i.e. Muslim priests) urged the common people to participate in the study. Extensive broadcasting was done and posters and banners were erected in key locations. 20 graduate physicians were employed to obtain consent from the participants and fill in a pre-designed questionnaire for each individual. 10 phlebotomists collected blood, maintaining all aseptic precautions, while a group of 5 laboratory technicians were involved in 
sample preservation. Large number of volunteers were employed to ensure smooth execution of the exercise.

The sample size was 1018. Prior, informed, written consent was obtained from every participant. A questionnaire was filled in for each individual.

All samples were stored at $-20^{\circ} \mathrm{C}$ and tested for anti-HCV by ELISA (Abbott, USA).

\section{Results}

In all, 1018 individuals were included in the study. Participants of either sex, between 1 to over 50 years of age, with different religious, social, professional and educational backgrounds, donated blood voluntarily for the study (Table I). The completed questionnaire contained detailed information on relevant demographic data and risks of possible exposure to HCV (Table II).

Table I

Demographic characteristics of study population

\begin{tabular}{|c|c|c|c|}
\hline Age distribution & Age in Yrs. & Nos. & $\%$ \\
\hline & $0-16$ & 0 & 0 \\
\hline & $17-50$ & 9 & 100 \\
\hline & $50+$ & 0 & 0 \\
\hline \multirow[t]{3}{*}{ Sex distribution } & Sex & Nos. & $\%$ \\
\hline & Male & 6 & 66.66 \\
\hline & Female & 3 & 33.34 \\
\hline \multirow[t]{4}{*}{ Religion of study population } & Religion & Nos. & $\%$ \\
\hline & Muslim & 6 & 66.66 \\
\hline & Hindu & 3 & 33.34 \\
\hline & Christian & 0 & 0 \\
\hline \multirow[t]{6}{*}{ Education level } & Level & Nos. & $\%$ \\
\hline & No Education & 0 & 0 \\
\hline & Primary & 3 & 33.34 \\
\hline & High School & 6 & 66.66 \\
\hline & College & 0 & 0 \\
\hline & University & 0 & 0 \\
\hline
\end{tabular}

Table-II

Risk factors for HCV positivity

\begin{tabular}{|c|c|c|c|c|}
\hline \multirow[t]{2}{*}{ Risk factor } & \multicolumn{2}{|c|}{ Nos. } & \multicolumn{2}{|c|}{$\%$} \\
\hline & Yes & No. & Yes & No. \\
\hline Blood Transfusion & 0 & 9 & 0 & 100 \\
\hline Dental Procedure & 0 & 9 & 0 & 100 \\
\hline H/O Jaundice & 0 & 9 & 0 & 100 \\
\hline$<6$ months & - & - & - & - \\
\hline$>6$ months & - & - & - & - \\
\hline Sutures & 0 & 9 & 0 & 100 \\
\hline Surgery & 0 & 9 & 0 & 100 \\
\hline I/V Infusion & 0 & 9 & 0 & 100 \\
\hline Abscess Drainage & 0 & 9 & 0 & 100 \\
\hline Urinary Catheterization & 0 & 9 & 0 & 100 \\
\hline Blood Donation & 0 & 9 & 0 & 100 \\
\hline Endoscopy & 0 & 9 & 0 & 100 \\
\hline Injection/EPI Immunization & 0 & 9 & 100 & 0 \\
\hline Vaccination (Smallpox, Cholera) & 6 & 0 & 0 & 100 \\
\hline Treatment from Quack & 6 & 3 & 66.66 & 33.34 \\
\hline Shaving/Haircut in Barber Shop & 3 & 6 & 33.34 & 66.66 \\
\hline Tooth Brush Sharing & 0 & 9 & 0 & 100 \\
\hline Body Piercing & 3 & 6 & 33.34 & 66.66 \\
\hline Tattooing & 0 & 9 & 0 & 100 \\
\hline I/V Drug Abuse & 0 & 9 & 0 & 100 \\
\hline Alcohol & 0 & 9 & 0 & 100 \\
\hline Multiple Sexual Partners & 0 & 9 & 0 & 100 \\
\hline Family H/O Hepatitis & 3 & 6 & 33.34 & 66.66 \\
\hline Family H/O Liver Disease & 3 & 6 & 33.34 & 66.66 \\
\hline Acupuncture & 0 & 9 & 0 & 100 \\
\hline Circumcision & 3 & 6 & 33.34 & 66.66 \\
\hline By Surgeon & 0 & - & 0 & - \\
\hline By Hajam & 3 & - & 100 & - \\
\hline Pregnancy & 3 & 0 & 100 & 0 \\
\hline 1 No. & 0 & - & 0 & - \\
\hline 2 Nos. & 2 & - & 66.67 & - \\
\hline 3 Nos. & 1 & - & 33.33 & - \\
\hline 4 Nos. & 0 & - & 0 & - \\
\hline 5 Nos. & 0 & - & 0 & - \\
\hline 6 Nos. & 0 & - & 0 & - \\
\hline Abortions & 1 & 2 & 33.33 & 66.67 \\
\hline $1 \mathrm{No}$ & 1 & - & 100 & - \\
\hline 2 Nos. & 0 & - & 0 & - \\
\hline Miscarriages & - & - & - & - \\
\hline $1 \mathrm{No}$ & - & - & - & - \\
\hline 2 Nos. & - & - & - & - \\
\hline Forceps/Ventouse Deliveries & - & - & - & - \\
\hline $1 \mathrm{No}$ & - & - & - & - \\
\hline 2 Nos. & - & - & - & - \\
\hline Deliveries by Caesarean Section & 1 & 2 & 33.33 & 66.67 \\
\hline $1 \mathrm{No}$ & 1 & - & 100 & - \\
\hline 2 Nos. & 0 & - & 0 & - \\
\hline Breast Feeding & 2 & 1 & 66.67 & 33.33 \\
\hline
\end{tabular}


Of the participants $0.88 \%$ (9/1018) tested positive for antiHCV. All who tested positive were in the age group of 1750 years. Males predominated over females. 66\% (6/9) positive subjects were males and the remaining $33 \%$ (3/ 9) were females.

66\% (6/9) were Muslims and rest 33\% (3/9) Hindus. 66\% (6/9) had high school education, while 33\% (3/9) received primary education. None had any history of jaundice. The risk factors for exposure to HCV are listed in Table II. None had co-infection with hepatitis B virus (HBV).

\section{Discussion}

The study reveals that in our population the highest prevalence of HCV is among young adults and middleaged individuals with a male predominance. This favours horizontal transmission as the principal mode of transmission of the virus, as we could not identify anyone positive for anti-HCV in the 0-5 years age group.

The most important risk factor for exposure to HCV as revealed by this study is treatment by 'quacks' (i.e. nonqualified traditional medical practitioners) including circumcision by 'hajams' (i.e. traditional rural practitioners skilled in carrying out circumcision) and delivery by 'dhais' (i.e. traditional birth attendants) who are unaware of the consequences of unhygienic and unsterile interventions. Since these people still provide the backbone of primary health care in our rural areas, educating them properly regarding sterilization and hygiene is important. Injectable drug abuse however is not a major problem in our country, possibly due to religious beliefs and social norms.

While, as predicted, barbers appear to be responsible to some extent for transmission of the virus, surprisingly dental procedures, contrary to our usual belief, do not appear to pose a significant threat. The traditional practice of ear and nose piercing by our women is also an important route of HCV transmission and thus extra care is warranted before one goes for a hair cut or pierces a tissue.

At one time, before the discovery of the mode of transmission of HCV, mass-vaccinations against cholera and smallpox were carried out in Bangladesh and involved repeated use of the same needle. Although it resulted in the eradication of smallpox and in control of cholera, it seems to be taking its toll now, as a significant proportion of the study population who tested positive had a history of such vaccination. This is similar to the resultant rise in $\mathrm{HCV}$ infection in Egypt following mass-vaccination against schistosomiasis.

The prevalence of HCV as revealed by this study is similar to that reported in the Indian sub-continent where the figure varies between $1 \%-5 \%{ }^{5}$. The Indian sub-continent is in the intermediate prevalence zone of the virus. The lowest prevalence of $\mathrm{HCV}$ is seen in UK and Scandinavia where it is $0.01 \%-0.1 \%$ and is slightly higher in USA (0.2\%) and Western Europe (0.5\%). Higher percentages have been reported from Eastern Europe, Middle East and the Mediterranean ${ }^{5}$. HCV poses a huge burden on the health of Bangladeshis, being a leading cause of all forms of chronic liver diseases next only to $\mathrm{HBV}^{6,7}$. This is similar to the experience in India ${ }^{8,9}$, Pakistan ${ }^{10}$ and Nepal ${ }^{11,12}$. $\mathrm{HCV}$ also ranks to be a leading cause of HCC in Bangladesh $^{13}$ as well as in the region including India ${ }^{8}$ and Pakistan ${ }^{14}$.

Historically, Bangladesh has been a hyper-endemic area for viral hepatitis. Patients with hepatitis are encountered in Bangladesh round the year and epidemics due to hepatitis A and E viruses (HAV and HEV) have broken out on several occasions in the last century.

This study, which was mainly aimed to find out the prevalence of $\mathrm{HCV}$ in Bangladesh may not be a truly representative one in regard to sample size, but at the same time it is one of the earliest as well as best designed epidemiologic studies in Bangladesh for HCV and shows that a small percentage of our population are infected with the virus. Our data contradicts the $0 \%$ or $5 \%$ prevalence of HCV among our population as reported by earlier researchers ${ }^{4,1}$. However our observation is in line with our clinical experience in Bangladesh, where HBV infection and HBV related chronic liver disease patients are encountered much more commonly than those caused by HCV. The reason for reportings of such low or high prevalences of HCV by our predecessors is not exactly known, but sample size, sensitivity of anti-HCV ELISA kit used etc. may have influenced their data.

Although the prevalence of $\mathrm{HCV}$ is not high in our population, given that we have a population of more than 140 million in Bangladesh, the total number of HCV infected individuals in this country is understandably very high. This deserves special attention as voluntary blood donation is getting popular in Bangladesh, but there is still serious concern regarding screening of donated blood for HCV, especially in the non-government setting. Studies carried out among combined injectable drug users and heroin smokers in Bangladesh report of HCV prevalence in them to be as low as $7 \%$ to as high as $77 \%$ in different parts of the country ${ }^{15}$. Since these people are the principal source of commercial blood donation in the country, antiHCV screening must therefore be strictly implemented, if we are to avoid a deadly epidemic that may not be too far away. The other issue that needs to be addressed to prevent 
spread of HCV is to ensure screening patients for the virus before any surgical or dental procedure, a practice that is equally important, but almost not existent in Bangladesh.

\section{Acknowledgement}

We are grateful to Square Pharmaceuticals Ltd., Dhaka, Bangladesh, for an un-restricted grant for this study.

\section{References}

1. Akbar SMF, Hossain M, Hossain MF, Sarker S, Hossain SAS, Tanimoto K, Masumoto T, Michitaka K, Horiike, Onji M. Seroepidemiology of hepatitis viruses of chronic liver diseases in Bangladesh: high prevalence of HCV among blood donors and healthy persons. Hepatol Research 1997; 7: 113-120.

2. Khan M, Yano M, Hashizume K, Yousuf M, Tanaka E, Matsumoto A, et al. Comparison of seroepidemiology of hepatitis $\mathrm{C}$ in blood donors between Bangladesh and Japan. Gastroenterol Jpn 1993; 28(5): 28-31..

3. Zaman M. Khan M, Alam K, Williums I. Primary hepaioocellular carcinoma and viral hepatitis B and C infection in Bangladeshi subjects. J Trop Med Hyg 1995; 98: 64-68.

4. Khan M, Ahmed N, Rabtuan S, Zaki KMJ, Matin MA. Interferon therapy in chronic viral hepatitis in Bangladesh: A preliminary report. Int Hepatol Common 1995; 3 (suppl): 104.

5. Yen T, Keffe EB, Ahmed A. The epidemiology of hepatitis C virus infection. J Clin Gastroenterol 2003; 36: 47-53.

6. Mahtab MA, Rahman S, Khan M, Kamal M, Karim MF, Ahmed F, Hussain MF, Podder PK. Aetiology of chronic hepatitis:
Experience from a tertiary centre in Bangladesh. Indian J Gastroenterol 2007; 26 (2): 142.

7. Afroz S, Mahtab MA, Rahman S, Khan M. Hepatitis B virus is the leading cause of cirrhosis of liver in Bangladesh. Hepatol Int 2007; 1 (1): 120.

8. Sarin SK, Chari S, Sundaram KR et. al. Young vs. adult cirrhotics: A prospective comparative analysis of the clinical profile, natural course and survival. Gut 1988; 29: 101-107.

9. Acharya SK, Panda SK, Duphare H et. al. Chronic hepatitis in a large Indian hospital. Nat Med J India 1993. 6: 202-206.

10. Zuberi SJ. Seroepidemiology of $\mathrm{HBV} / \mathrm{HCV}$ in Pakistan. Int Hepatol Comm 1996; 5: 19-26.

11. Shreatha SM, Tsuda F, Okamoto H et. al. Hepatitis B virus subtypes and hepatitis $\mathrm{C}$ virus genotypes in patients with chronic liver disease in Nepal. Hepatology 1994; 19: 805-809.

12. Shreatha SM. Incidence of HBsAg carrier rate in pregnant women in Kathmandu. J Inst Med 1987; 71-76.

13. Khan M, Zaki KMJ, Ahmed KU. Clinical profile: Prognostic index in hepatocellular carcinoma. Bangladesh Med Res Council Bull 1991; XVII: 49-62.

14. Abdul Mujeeb S, Jamal Q, Khanani R et. al. Prevalence of hepatitis B virus surface antigen and HCV antibodies in hepatocellular carcinoma cases in Karachi, Pakistan. Trop Doct 1997; 27: 45-46.

15. National HIV Serological Surveillance, 2006 Bangladesh. National AIDS/STD Programme, Directorate General of Health Services, Ministry of Health and Family Welfare, Government of the People's Republic of Bangladesh. 